\title{
SISTEMA FLUVIAL E PLANEJAMENTO LOCAL NO SEMIÁRIDO
}

\author{
fluvial system and local planning \\ Jonas Otaviano Praça de Souza* \\ Antonio Carlos de Barros Corrêa**
}

\begin{abstract}
Resumo
O presente estudo analisou um sistema fluvial semiárido e suas características físicas, com foco nos processos geomorfológicos e formas resultantes, como também nas relações destas com as atividades antrópicas, com vistas à utilização desses dados no planejamento local. A pesquisa foi realizada no município de Belém de São Francisco, Pernambuco, Mesorregião do São Francisco, na bacia do riacho Mulungu, localidade submetida a um clima semiárido com chuvas de verão e cobertura da terra com predominância da caatinga arbustiva aberta. Tomou-se como procedimento metodológico a realização de mapeamentos geomorfológicos em várias escalas e com diferentes ênfases, a fim de avaliar de forma hierárquica as relacõoes entre os diversos compartimentos, substratos geológicos e formas de uso da terra. A partir das informações espaciais obtidas nos diversos níveis de detalhamento cartográfico do sistema fluvial, pôde-se realizar uma avaliação ambiental da área, tomando-se por base a dinâmica erosiva/deposicional ao longo do canal, bem como a relação deste com suas margens. Concluiu-se que as formas de acumulação no plaino aluvial apresentam controles de origem antropogênica, relacionadas aos tipos tradicionais de uso da terra na bacia. Esses controles, tais como a construção de barragens ao longo do leito, atuam modificando processos e criando novas morfologias deposicionais dentro do sistema fluvial, que por sua vez passam a redefinir as formas de uso na área.
\end{abstract}

Palavras-chave: Geomorfologia fluvial, Semiárido, Mapeamento geomorfológico, Estilo fluvial.

\begin{abstract}
The present study has analyzed a semi-arid fluvial system and its physical attributes, focusing on resulting geomorphological processes and forms, as well as on their relationship with human activity as a tool for local planning. The research was carried out in the municipality of Belém do São Francisco, Pernambuco State, São Francisco region, in the watershed of Mulungu creek, an area which is subjected to a semi-arid climate with summer downpours, with a land cover dominated by open thorn-brush vegetation. The methodology applied was the conduction of geomorphological mapping within several scales, emphasizing different land surface aspects, aimed at assessing the hierarchic relationships amongst landforms, geologic basement, and land use typologies. Based on the acquired spatial information in different detailing mapping levels of the fluvial system, it was possible to carry on an environmental assessment of the area, based on the erosive/ depositional dynamics along the channel as well as its relation with its margins. The study concluded that accumulation forms within the fluvial realm exhibit man-induced controls, related to the traditional types of land use within the watershed. Controls, such as the building of dams along the channel, act modifying processes and creating new depositional features in the fluvial system, which at last contribute to reshape land use practices in the area.
\end{abstract}

Key words: Fluvial geomorphology, Semi-arid environment, Geomorphological mapping, River styles.

\section{Resumen}

El presente estudio analiza un sistema fluvial semiárido y sus características físicas, centrándose en los procesos geomorfológicos y las formas resultantes, sino también en las relaciones con las actividades humanas, con el fin de utilizar dichos datos en la planificación local. La encuesta se llevó a cabo en el municipio de Belém do São Francisco, en Pernambuco, mesorregión del São Francisco en la cuenca del arroyo Mulungu, lugar expuesto a un clima semi-árido con lluvias de verano, y la cobertura del suelo con un predominio de la caatinga arbustiva abierta. Se tomó como procedimiento metodológico la cartografía geomorfológica a diferentes escalas y con diferentes énfasis, para evaluar la relación jerárquica entre los distintos compartimentos, sustratos geológicos y formas de uso de la tierra. De la información espacial obtenida en los distintos niveles de la cartografía detallada del sistema fluvial, se realizó una evaluación ambiental de la zona, teniendo como base la dinámica erosiva/deposicional a lo largo del canal y su relación con sus bancos. Se concluyó que las formas de acumulación en la llanura aluvial exhiben controles de origen antropogénico, vinculados a los tipos tradicionales de uso del suelo en la cuenca. Estos controles, como la construcción de represas a lo largo del canal, actúan cambiando a los procesos de creación de nuevas morfologías de depósito en el sistema fluvial, que a su vez comienzan a redefinir los tipos usos de la zona.

Palabras clave: Geomorfología fluvial, Ambiente semiárido, Cartografía geomorfológica, Estilos fluviales.

(*) Doutorando no Programa de Pós-Graduação em Geografia da Universidade Federal de Pernembuco - Cidade Universitária, Av. Acadêmico Hélio Ramos, s/n, CEP: 50.670-901, Recife (PE) - Brasil. Tel.: (+55 81) 21268277 -jonasgeoufpe@yahoo.com.br

(**) Bolsista Produtividade do CNPq, Prof. Dr. do Programa de Pós-Graduação em Geografia da Universidade Federal de Pernembuco - Cidade Universitária, Av. Acadêmico Hélio Ramos, s/n, CEP: 50.670-901, Recife (PE) - Brasil. Tel.: (+55 81) 21268277 - antonio.correa@ufpe.br 


\section{INTRODUÇÃO}

A pesquisa em tela voltou-se para o entendimento de um sistema geomorfológico fluvial semiárido e as interferências antrópicas sobre a morfologia do mesmo. Para tanto foram realizados mapeamentos geomorfológicos em diversas escalas de detalhe da área pesquisada, visando recompor, a partir da análise da gênese dos estilos fluviais do canal principal do riacho Mulungu, a dinâmica geomorfológica do sistema.

Botelho (2005) propõe o uso da bacia como unidade básica de planejamento, tratando-a como uma unidade espacial sistêmica. Assim, a realização do estudo em diversas escalas de detalhe permitiu um enfoque sistêmico dos aspectos geomorfológicos da bacia, decompondo-a em subsistemas que possibilitaram a construção de diagnósticos mais detalhados, viabilizando, deste modo, a apreciação da organização do sistema geomorfológico e suas interações complexas (BRUNSDEN e THORNES, 1979; CHRISTOFOLETTI, 1980).

A análise foi realizada na bacia do riacho Mulungu, localizada no município de Belém de São Francisco-PE, a $500 \mathrm{~km}$ do Recife (figura 1); inserida na bacia do rio Pajeú, afluente do Rio São Francisco. O clima regional é tropical semiárido, com precipitação anual média de $470 \mathrm{~mm}$ (para a área da bacia), sendo fevereiro e março os meses mais chuvosos. A vegetação natural é a caatinga arbustiva, onde o comportamento decíduo da vegetação aliada com a concentração e características das chuvas geram, naturalmente, uma forte produção de sedimentos nesse tipo de ambiente (LEOPOLD, WOLMAN e MILLER, 1964; WALLING e WEBB, 1996).

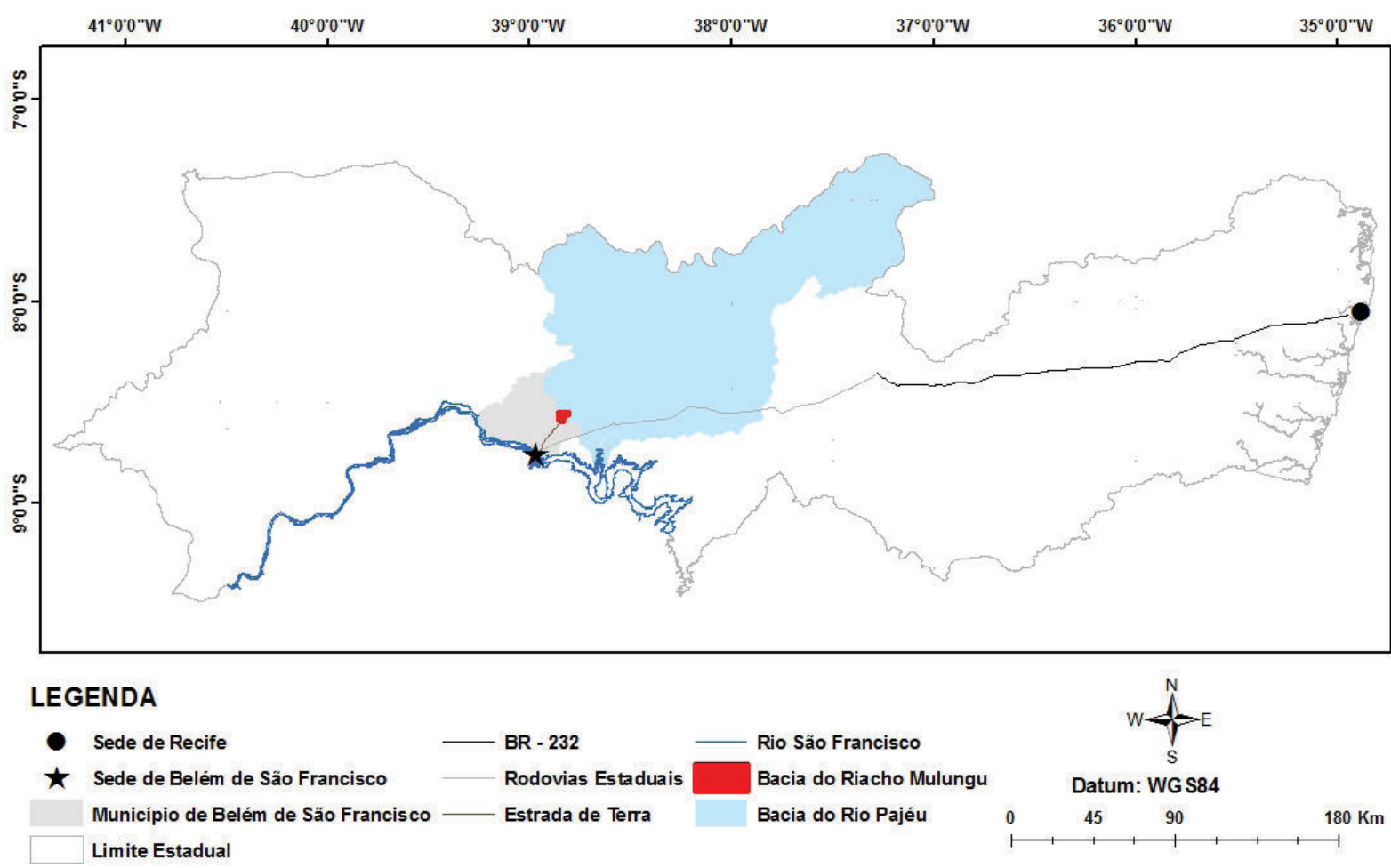

Figura 1 - Mapa de localização da bacia do Riacho Mulungu

Regionalmente a bacia está situada na Depressão Sertaneja, na margem esquerda da calha do rio São Francisco, em um setor no qual a variação altimétrica é de 300m a 500m (EMBRAPA, 2001). Predominam na área rochas mesoproterozóicas da Província Borborema, localmente representadas pelos litotipos metamorfizados dos complexos Belém do São Francisco, Cabrobó, Floresta e Sertânia, além de metagranitóides (CPRM - SERVIÇO GEOLÓGICO DO BRASIL , 2005).

A cobertura pedológica observada na região de estudo é marcada por associações de luvissolos, com a presença também de neossolos litólicos, neossolos flúvicos, planossolo, como também 
afloramentos rochosos. Sendo os luvissolos presentes nas rampas de pedimentos, os planossolos nas baixadas marginais às calhas dos riachos, e os neossolos litólicos e afloramentos de rocha nos topos dos interflúvios (CORRÊA, SOUZA e CAVALCANTI, em prelo).

A ocupação humana na bacia é representada pela comunidade Sítio dos Montes, localizada nas proximidades do baixo e médio curso do riacho Mulungu, composta de aproximadamente cinquenta famílias. Os residentes na Bacia têm como principal atividade a agricultura e pecuária com baixo aporte tecnológico, sendo a primeira realizada nas vazantes do riacho Mulungu e a segunda realizada extensivamente em toda área da bacia, tendo por pasto a vegetação nativa de caatinga aberta arbustiva.

Devido à proposta de integração/transposição das águas do Rio São Francisco torna-se crucial identificar todos os componentes paisagísticos que perfazem o sistema dessa bacia. Deste modo, a bacia analisada neste estudo está inserida em um arcabouço de fatores físicos e sociais semelhantes à grande parte do semiárido nordestino, em especial às áreas pedimentares, predominantes no Sertão de Pernambuco. Deste modo este estudo é representativo para outras áreas similares.

\section{FUNDAMENTAÇÃO TEÓRICA}

A partir da valorização dos estudos interdiciplinares na ciência moderna tornou-se necessário a utilização de um paradigma científico que vise uma integração do conhecimento e das características analisadas. Dentro dessa perspectiva, consolidaram-se os estudos sistêmicos, quase sempre trabalhados/citados nos estudos que trabalham a bacia hidrográfica como objeto ou recorte espacial. Deste modo, a abordagem sistêmica apresenta-se como meio de compreensão do mundo natural, assim possibilitando a previsão de mudanças, avaliação dos sistemas ambientais, interferências e limiares do sistema (THORNES e BRUNSDEN, 1977; MATTOS e PEREZ FILHO, 2004; DREW, 2005).

A partir da ideia de bacia hidrográfica como recorte espacial é fundamental encontrar uma episteme sistêmica que suporte a analise integrada dos diferentes elementos em estudos sobre o ambiente fluvial. Tanto na analise dos processos, quanto em relação à estrutura do sistema; levando em consideração os elementos externos a rede de drenagem, quanto os elementos presentes na rede de drenagem, em especial a questão sedimentológica, muitas vezes esquecida na analise e gestão dos recursos hídricos. Christofoletti (1999) coloca que "o fluxo e o material sedimentar são os dois componentes fundamentais a estruturação do canal fluvial", deste modo não se pensar em gestão de recursos hídricos sem analisar as questões sedimentológicas. Inserido nesta perspectiva está o conceito de sistema fluvial, que é entendido como a zona fonte de sedimentos, a rede de transporte e os sítios de deposição. Esses elementos não são espacialmente excludentes, interagindo entre si, além de apresentar escalas diferenciadas. Para compreender as inter-relações, ou algum dos elementos em separado; é necessário compreender o comportamento dos rios, o aporte de água na zona fonte de sedimento, qual quantidade e tipo de sedimento disponível, como são os controles climáticos e geológicos e o que eles afetam, qual o uso do solo e cobertura vegetal e sua relação com as zonas do sistema fluvial, etc (SCHUMM, 1977).

Os processos geomórficos, regimes de fluxo, vegetações associadas e a disponibilidade de sedimentos (balanço sedimentológico) irão modificar as forças de distribuição de energia e matéria dentro do sistema fluvial, e essa interação irá determinar as características e distribuição dos elementos do sistema (BRIERLEY e FRYIRS, 2005). Tornando, assim, necessário o estudo da distribuição e características dos elementos do sistema fluvial para a compreensão dos processos fluviais, sendo assim sendo possível associar as formas e características identificadas com os processos atuantes nesses sistemas.

Ao falar dos ambientes de terras secas (árido, semiárido e subúmido) Graf (1998), no livro "Fluvial Process in Dryland Rivers", defende que apesar da pouca precipitação a morfologia dessas áreas está estritamente ligada à ação dos rios. A partir dessas ideias o foco do presente trabalho será localizar as formas geomorfológicas da bacia e identificar suas características, em diversas escalas 
e com ênfase nos ambientes fluviais; para tanto algumas características das formas predominantes serão expostas.

As formas mais vastas e comuns nas terras secas, normalmente, são os pedimentos. Superfícies cristalinas suavemente inclinadas, esculpidas em rochas homogêneas, ou não, localizadas a partir do sopé de uma escarpa (SUGUIO, 1998). A mudança entre a escarpa e o pedimento dá-se a partir de uma ruptura brusca de ângulo (knickpoint); podendo existir uma delgada cobertura detrítica colúvio-aluvial, mal selecionada e não estratificada, havendo essa cobertura a forma é chamada de pedimento detrítico (CHRISTOFOLETTI, 1980). Este pavimento detrítico tem sua gênese relacionada com a remoção dos sedimentos finos pelo escoamento superficial não canalizado (SCHUMM, 1977). Contudo, o pedimento pode ser formado em outros climas, além das terras secas, como também em embasamento sedimentar; contudo é sob os climas áridos e semiáridos e em embasamento cristalino que os pedimentos apresentam um maior desenvolvimento (GRAF, 1988).

As características do fluxo e da carga sedimentar dos canais nas terras secas, aliadas com as características do substrato geológico e estado da vegetação do vale fluvial vão controlar as formas desenvolvidas nos canais e adjacências, formando um complexo de formas particulares, não exclusivas, das terras secas.

Os canais retilíneos, nas terras secas, ocorrem quando há um controle litológico das margens e uma maior declividade, normalmente próximo das cabeceiras, onde não há um grande aporte de sedimentos no canal, sendo comum a sequencia de corredeiras e depressões no seu leito (GRAF, 1988). Eles também podem se encaixar em linhas de fraqueza e entalhá-las, sendo comuns canais retilíneos em áreas com forte controle estrutural (SCHUMM, 1977).

Os canais anastomosados apresentam um volume de sedimento formadores da carga de fundo até cinco vezes a carga de fundo de um canal não anastomosado (CHRISTOFOLETTI, 1980). A relação de longos períodos de estiagem, pouca cobertura vegetal favorecem o aumento da carga de fundo e a formação dos canais anastomosados (BIGARELLA, SUGUIO e BECKER, 1979).

Esse volume maior de carga de fundo é responsável pela formação de depósitos de areia e cascalho como barras, longitudinais e laterais, que podem sofrer processo de estabilização e transformar-se em ilhas. A quantidade de ilhas e barras no canal o subdivide, assim os canais anastomosados são formados por diversos "sub-canais" entrecortados pelas ilhas e pelas barras (BIGARELLA, SUGUIO e BECKER, 1979; CHRISTOFOLETTI, 1981). Durante as cheias há rápidas mudanças na localização e geometria desses canais, podendo gerar, através de relocação lateral, os chamados canais enterrados (GRAF, 1988).

Os rios meandrantes desenvolvem formas diferentes em relação aos canais anastomosados, um dos motivos é a diferença do volume de carga de fundo. Os depósitos comumente associados a esses canais são as barras de meandro que apresentam granudescendência ascendente, com os matérias grosseiros na base e os finos no topo, porém é comum quebras na granudescendência (GRAF, 1988).

O fluxo em canais meandrantes sofrem alterações de velocidade e direção havendo uma alternância erosiva entre as margens, ou seja, na curvatura dos meandros a margem côncava será erodida e a margem convexa sofre deposição de barras de meandros; esse processo também gera a migração lateral do canal (LEOPOLD, WOLMAN e MILLER, 1964).

As planícies de inundação apresentam, em terras secas, múltiplos níveis acima do nível do canal, isso resulta da grande variação das magnitudes das cheias, alguns patamares (níveis) das planícies de inundação podem permanecer anos ou décadas sem serem atingidos novamente (THOMS, 2003), sendo possível encontrar vários níveis diferentes sob o nível atual da planície; normalmente os canais anastomosados não apresentam planícies de inundação adjacente (GRAF, 1988). Em áreas agrícolas com baixo aporte tecnológico, nas terras secas, o desenvolvimento econômico das populações está ligado às planícies de inundação (THOMS, 2003).

Entre os diversos impactos resultados das atividades antrópicas nos rios de terras secas o de maior significado são as construções de barramentos nos rios. Os impactos influenciam tanto 
a montante quanto a jusante do barramento. Inicialmente, a montante, há a mudança do nível de base, que fica ajustado ao nível da água, contudo esse novo nível de base não é constante seguindo as flutuações do nível de água do reservatório. Causando uma série de modificações nos processos associados, parte processos fluviais e parte processos lacustres (GRAF, 1988). Caso haja a retirada do barramento do canal, há a possibilidade que os processos lacustres tenham formado uma planície lacustre com características semelhantes às planícies de inundação em relação ao uso agrícola.

A mudança no nível de base modifica a velocidade do fluxo, diminuindo a velocidade o que gera um aumento da sedimentação a montante, gerando retroalimentações que modificam as formas e os processos associados. O maior nível de sedimentação ocorre nos primeiros anos, indo aos poucos se estabelecendo um novo equilíbrio (GRAF, 1988). A sedimentação a jusante pode preencher canais de menor porte, ravinas/voçorocas e canais entrincheirados; como também diminuir a profundidade do canal principal, que ao ajustar-se acaba ampliando suas margens, como também durante o processo de ajuste haja a formação de planícies de inundação. A distância afetada pela mudança de nível de base é variável para cada sistema fluvial, de centenas de metros a alguns quilômetros (LEOPOLD, WOLMAN e MILLER, 1964).

A jusante os barramentos impõe uma mudança drástica no regime do rio, diminuindo consideravelmente o volume do fluxo, e aprisionando grande parte do sedimento transportado. $\mathrm{O}$ fluxo liberado contém baixa carga de sedimentos, deste modo apresenta uma maior capacidade erosiva que resulta em um aumento da erosão a jusante da barragem (GRAF, 1988).

\section{METODOLOGIA DOS MAPEAMENTOS}

A principal dificuldade para a realização dos mapeamentos foi é a não disponibilidade de dados analógicos de grande escala para a área estudada, deste modo optou-se trabalhar com dados cartográficos digitais.

A construção a partir de uma base cartográfica rígida do mapa planialtimétrico pode ser realizada de maneira célere a partir da utilização de SIGs e de bases de dados SRTM - Shuttle Radar Topography Mission (GUIMARÃES, LANDAU e COSTA, 2008), no caso da atual pesquisa foi escolhido trabalahr com os dados TOPODATA (VALERIANO, 2005) pela sua maior precisão em relação aos dados SRTM. Carvalho e Latrubesse (2004) apontam uma superioridade no uso de MDE, também chamados de modelos digitais de terreno - MDT, em relação ao uso de cartas topográficas tradicionais:

O uso de cartas topográficas não permite uma real interpretação das feições morfológicas do terreno, apresentando um traçado topográfico mais homogêneo com relação aos transectos elaborados em MDTs. A homogeneização, provocada por perfis elaborados de cartas topográficas, poderá ocultar formar do relevo, suavizando acidentes topográficos, e consequentemente, gerando produtos com valores de declividade e geoformas que não representam a verdade terrestre. (CARVALHO e LATRUBESSE, 2004, p. 88)

A geração de modelos digitais de elevação (MDE) a partir de dados SRTM é corriqueira na ciência geomorfológica (CARVALHO e LATRUBESSE, 2004; OLIVEIRA e RODRIGUES, 2007; VALERIANO e ROSSETTI, 2008; CARVALHO e BAYER, 2008), porém a maior parte dos trabalhos tem como objetivo mapeamento de macroescalas, a partir de 1:100000. Com o aporte de dados de melhor resolução como os dados TOPODATA, que apresentam resolução espacial básica de $30 \mathrm{~m}$ frente os $90 \mathrm{~m}$ de resolução dos dados SRTM, abrem-se novas possibilidades para a utilização desses dados na geração de MDE's e mapeamentos associados, podendo assim ser utilizados em mapeamentos de maior detalhe, principalmente quando se trabalha, também, com dados de campo ou de outras fontes para a realização dos mapeamentos.

Assim, o modelo digital de elevação (MDE) foi confeccionado a partir de informações de gabinete obtidas através do processamento de dados TOPODATA, disponíveis na Internet, utilizando 
o software Arcgis 9.3, disponível no Departamento de Ciências Geográficas da UFPE. A partir do processamento dos dados TOPODATA, também foi possível a delimitação da bacia de drenagem do riacho do Saco, identificação da rede de drenagem, a confecção de mapas hipsométricos e um mapa de declividade, necessários para a construção do mapa geomorfológico.

Em relação aos mapeamentos da rede de drenagem da bacia utilizou-se, também, dados obtidos em campo através de GPS (dois foram utilizados, o GPS Garmim Etrex VistaHcx), como também de imagens georeferênciadas QUICKBIRD (PINHEIRO, KUX e VILLWOCK, 2005). A partir desses dados adicionais a posição e geometria em planta dos canais fluviais foram corrigidas, aumentando assim o detalhamento das informações sobre a rede de drenagem, como também foram identificados e mapeados os corpos d'água, classificando-os em represamentos naturais e represamentos artificiais. A base do mapeamento foi gerada a partir do MDE (OLIVEIRA, CARVALHO JUNIOR, et al., 2007) trabalhado no ArcGis 9.3 utilizando o modulo de ferramentas hydrology, onde foi identificado tanto a área da bacia quanto a rede de drenagem.

Argento (1998) defende que ao se fazer um mapeamento temático geomorfológico; visando a analise ambiental, gestão ambiental ou territorial; não é necessário um emprego de técnicas detalhadas, porque sua base está relacionada com mapas planialtimétricos e esses, sim, devem ser construídos a partir de uma base cartográfica rígida; contudo ainda é necessário seguir regras cartográficas básicas para haver uma padronização confiável dos resultados (ARGENTO, 1998). Neste contexto os dados TOPODATA representariam dados rígidos que podem ser utilizados para gerar informações planialtimétricas.

O mapeamento geomorfológico enfatizou a morfologia e morfometria das formas de relevo, introduzindo a declividade ao mapeamento e deste modo integrando a análise qualitativa com dados quantitativos importantes na avaliação do processos geomorfológicos (RODRIGUES e BRITO, 2000), sendo utilizados dados numéricos a partir da ideia de superioridade dos dados numéricos em relação aos adjetivos de proporção (LEOPOLD, WOLMAN e MILLER, 1964). Levando em consideração, também os fatos sociais que modificam formas e processos vigentes (MARTINELLI e PEDROTTI, 2001).

A legenda foi criada a partir de uma adaptação da nomenclatura proposta na metodologia dos estilos fluviais, que dá ênfase ao diferentes estilos morfológicos do plaino aluvial e nas características funcionais dos sistemas fluviais (BRIERLEY e FRYIRS, 2005) (FRYIRS e BRIERLEY, 2005). Ao mesmo tempo tentou-se homogeneizar as compartimentações geomorfológicas visíveis nessa escala.

Os dados utilizados para o mapeamento foram os dados do MDE e mapeamentos derivados, como também informações obtidas nos trabalhos de campo e a partir de imagens QUICKBIRD. O tratamento dos dados foi realizado a partir do SIG Arcgis 9.3, tentou-se detalhar o mapeamento para a escala de 1:25000, assim foi de extrema importância os dados obtidos em campo, para identificação dos padrões de cobertura superficial, e a analise das imagens QUICKBIRD para a delimitação precisa dos compartimentos geomorfológicos (PINHEIRO, KUX e VILLWOCK, 2005).

A partir da subdivisão dos trechos do canal principal, caracterizada no mapeamento geomorfológico de 1:25.000, escolheu-se duas áreas representativas de duas subdivisões morfológicas. Esse mapeamento não foi realizado para a parte não-confinada do riacho por esse haver sido enquadrado como uma variação do setor semi-confinado, em virtude de sua exígua representatividade espacial. Com o tratamento, em gabinete, dos dados de campo, foram confeccionados mapas de estilo fluvial e matrizes dos padrões fluviais (BRIERLEY e FRYIRS, 2005). A fim de complementar as informações referentes aos inputs antropogênicos sobre o sistema fluvial, também foi realizado um mapeamento do uso da terra na bacia.

Os mapeamentos de estilo fluvial foram realizados na escala 1:10.000, e tiveram como foco a morfologia, resultante ou não de processos fluviais, e tipos de materiais encontrados no canal fluvial e nas áreas adjacentes, como também formas e materiais antropogênicos. Esse mapeamento seguiu as propostas de Brierley \& Fryirs (2005).

As matrizes dos padrões fluviais foram construídas com base em observações mais amplas 
como: características do setor do rio, tipo de vale, forma do rio, textura do leito, unidades geomórfícas e vegetação associada; comportamento do rio; controles do sistema; e intervenções humanas. As matrizes foram realizadas a partir do modelo de interpretação de Brierley \& Fryirs (2005), adaptando-o às características do semi-árido nordestino e incluindo os processos e formas antropogênicas, característica marcante da área de estudo.

Seguindo a subdivisão com base no tipo de vale, foram realizados três mapeamentos geomorfológicos de detalhe em parcelas de $100 \mathrm{~m}$ por $100 \mathrm{~m}$, na escala de 1:2.500. Este nível de detalhamento esteve voltado para setores do canal de drenagem principal e seu entorno na direção das margens. Neste grau de aproximação pode-se observar variadas interações entre estrutura superficial, morfometria e morfologia não observadas nos mapeamentos anteriores. Também foi possível espacializar de forma acurada as formas de uso da terra.

A partir do cruzamento dos mapeamentos geomorfológicos e do uso da terra estabeleceu-se um modelo para o comportamento físico-natural do sistema fluvial, de uma forma que viabilizasse a avaliação do impacto antrópico sobre a distribuição das formas na bacia, principalmente ao longo do canal da drenagem principal.

\section{MAPEAMENTOS NA ESCALA DE 1:25.000}

A análise dos dados coletados in situ durante os trabalhos de campo, e daqueles provenientes do tratamento digital dos dados digitais em gabinete, permitiram inicialmente a elaboração de um mapa geomorfológico de detalhe na escala 1:25.000. A legenda foi criada a partir de uma adaptação da nomenclatura proposta por Brierley \& Fryirs (2005), que dá ênfase ao diferentes estilos morfológicos do plaino aluvial (figura 2). Na classificação tentou-se homogeneizar os compartimentos geomorfológicos visíveis nessa escala.

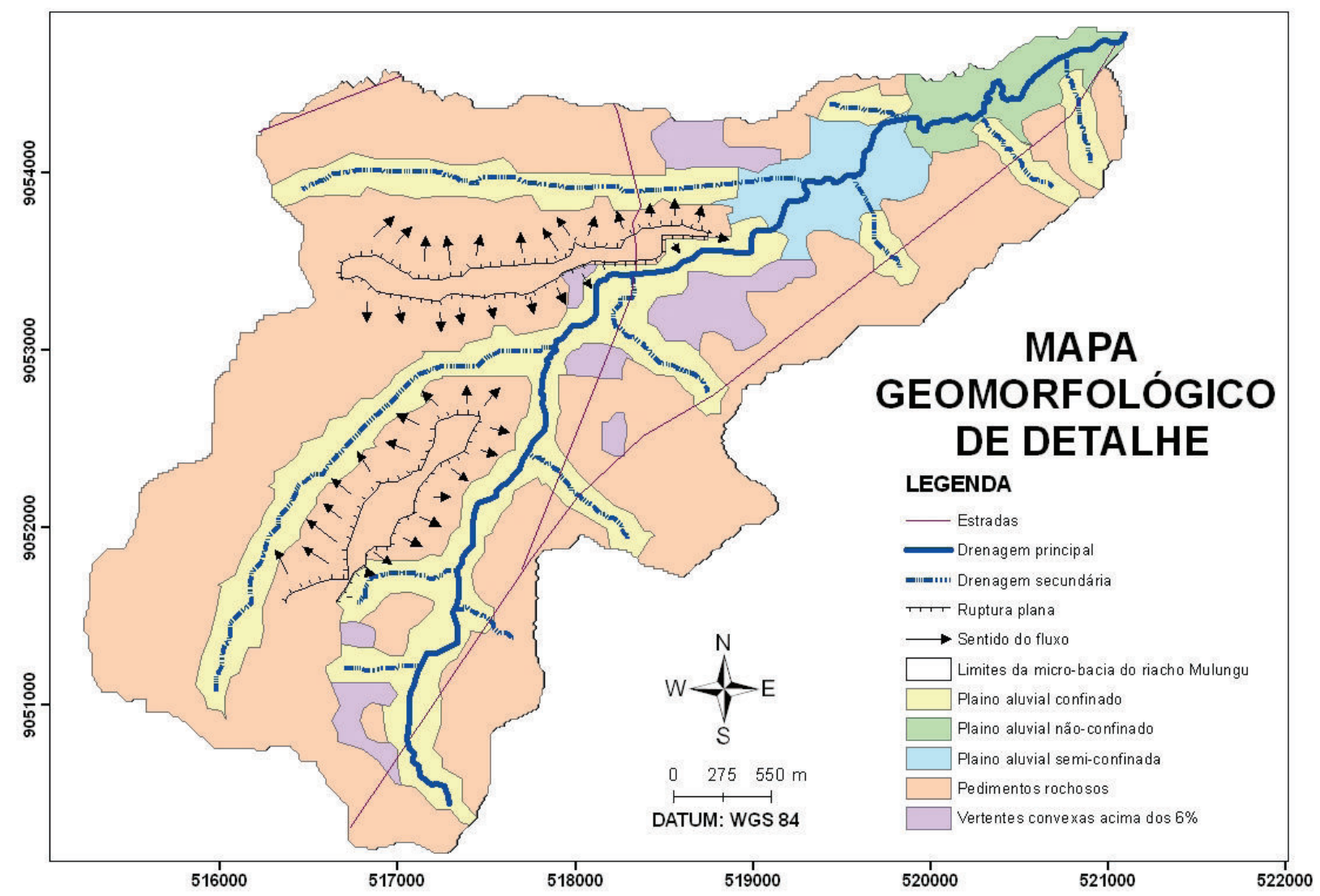

Figura 2 - Mapa geomorfológico de detalhe da microbacia do riacho Mulungu 
Formas de construção antrópicas, como as estradas, presentes na área da bacia, foram acrescidas ao mapeamento pelas mudanças causadas no comportamento hídrico, principalmente no alto curso do riacho Mulungu. As áreas de maior declividade também foram identificadas por representarem áreas excepcionais dentro da bacia, e pela maior propensão à erosão, devido ao aumento do seu valor.

A unidade "pedimento" foi descrita como superfície erosiva com gradiente baixo, de litologia cristalina, com recobrimento, geralmente, por pavimento detrítico (SUGUIO, 1998), resultado da remoção dos clastos mais finos pelo escoamento superficial não canalizado.

Com base no mapa geomorfológico de detalhe foi possível subdividir a bacia a partir da relação entre o canal e os interflúvios adjacentes, já que no caso da incisão fluvial em tela não se poderia considerar as relações entre o canal e um "vale" propriamente dito. Igualmente, a calha fluvial foi tomada como plaino aluvial, já que não há uma distinção precisa entre canal e planície, como ocorre com frequência nas bacias de menor ordem no semiárido. Assim, com base na interação entre o plaino fluvial e os interflúvios adjacentes, foi possível subdividir a bacia em três setores distintos: plaino aluvial confinado, semiconfinado e não confinado. Também foi observada a presença de dois interflúvios com a existência de rupturas planas entre o riacho Mulungu e dois de seus afluentes.

Ainda com base no cruzamento dos dados de campo com os dados gerados em gabinete, a partir da análise de imagens IKONOS, realizou-se o mapeamento de uso da terra da área (figura 3), novamente na escala de 1:25.000.

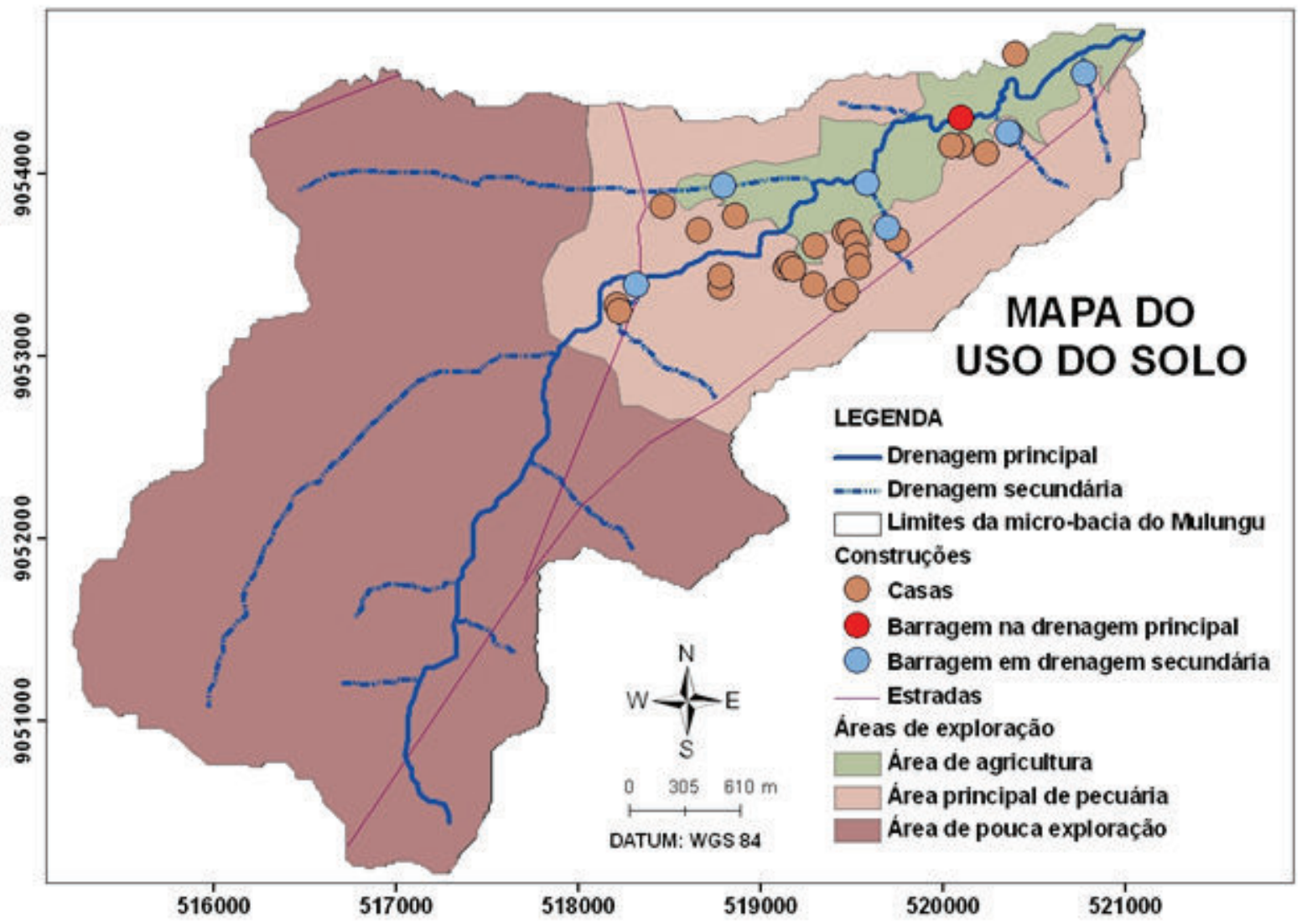

Figura 3 - Mapa de uso do solo da microbacia do riacho Mulungu

Foram delimitadas as principais áreas de pecuária extensiva, áreas de agricultura e assinaladas as principais construções, tais como casas, barragens e estradas. Foram consideradas áreas principais de pecuária extensiva aquelas em que há uma maior concentração do gado, principalmente caprino, durante todo o ano, normalmente nas áreas mais próximas às residências. Sabendo-se que o gado nas épocas secas fica livre e se alimenta por toda a área da bacia, é necessário considerar o impacto da pecuária em toda a bacia, apesar do mapeamento de uso da terra só apontar as áreas de maior impacto. 
Analisando o mapa geomorfológico e o mapa de uso da terra, observa-se que a ocupação humana na bacia está diretamente relacionada com a distribuição de unidades fluviais funcionais, ora predominantemente erosivas, no trecho onde o plaino aluvial se encontra confinado, ora deposicionais, nos curtos trechos finais onde predomina a formação de pequenas planícies "em bolsão", engastadas entre o canal propriamente dito e a base da ruptura de gradiente dos pedimentos rochosos dissecados. Desta forma, os cultivos estão espacialmente restritos às planícies em bolsão dos trechos semiconfinados e não confinados, enquanto a pecuária extensiva predomina sobre o trecho confinado e interflúvios em patamares aplainados. Observa-se que mais da metade da área da bacia é pouco explorada, havendo uma concentração de intervenções humanas no médio e baixo curso.

A partir dessa análise pode-se verificar vários impactos de origem antrópica. Inicialmente houve uma mudança da drenagem na cabeceira do riacho Mulungu, onde a estrada que atravessa o riacho em sua parte mais alta modifica o direcionamento de parte do fluxo nesta área da bacia, sendo esse fluxo direcionado de forma não canalizada paralelamente à estrada, não alimentando diretamente o canal principal.

Ainda em relação direta com a drenagem, existem inúmeras barragens ao longo dos canais secundários no médio e baixo curso do riacho, totalizando seis barragens em cinco afluentes, que alteram significativamente a oferta de água e principalmente de sedimentos para a drenagem principal, modificando assim as formas do canal.

A barragem no canal principal ocasionou mudanças na sua morfologia a montante e a jusante da intervenção. A montante o canal foi alargado e reteve grande quantidade de sedimentos, favorecendo, assim, a formação de planícies de inundação antropogênicas, como também produziu um visível processo de criação de meandros, ocasionado pela desaceleração do fluxo de água e por uma maior taxa de sedimentação.

O excedente de sedimento encontrado a montante dessa barragem forma uma espessa cobertura de sedimentos aluviais sobre o pedimento rochoso. A jusante pode-se observar um entalhe maior no canal fluvial e forte erosão linear, já formando uma rede de voçorocas, algumas com mais de 2 metros de profundidade, na área próxima ao "sangradouro" da barragem, que é em sua maior parte uma soleira rochosa.

As barragens também favoreceram uma maior salinização dentro do canal fluvial, podendo-se observar o afloramento de sais no leito do canal. Outro ponto a se destacar é o rompimento generalizado e cíclico que ocorreu nas barragens mapeadas nos anos com maior precipitação e aumento do fluxo de água. . No período dos trabalhos de campo realizados para esta pesquisa, apenas uma das barragens não estava rompida. Esses rompimentos recorrentes são diretamente influenciados pela diminuição da vida útil dos reservatórios, causada pela rápida colmatação que os reservatórios em ambientes semiáridos sofrem anualmente devido o grande aporte lateral de sedimentos. Esse fenômeno ocorre motivado pela combinação de chuvas fortes e concentradas, vegetação decídua e retirada da vegetação nativa da área.

Nas áreas onde a utilização da terra é mais intensa, principalmente nas áreas de agricultura, houve a retirada da vegetação ripariana, o que aumenta consideravelmente a perda de solo e as cicatrizes de erosão. Também se observou a presença de algumas espécies exóticas, como coqueiros e algarobas na zona ripária.

A concentração das habitações dá-se na área central da microbacia, na comunidade Sitio dos Montes. Observa-se ainda a quase inexistência de residências a jusante da barragem do curso principal, justificada por dois fatores: pelo rompimento da barragem, que ocorreu a mais de três décadas, e pela atração que a área a montante da barragem representava, a partir da reserva de água existente. Posteriormente ao rompimento da barragem, o problema causado pelos detritos gerados pela destruição do paredão, que recobriram o plaino aluvial a jusante da barragem, também contribuíram para a concentração de moradias a montante desta estrutura, mesmo após o seu desaparecimento. 


\section{MAPEAMENTOS EM OUTRAS ESCALAS}

Em seguida ao mapeamento da bacia na escala de 1:25.000, foram escolhidas áreas para mais duas escalas de mapeamento: o de estilos fluviais na escala de 1:10.000; e o mapeamento geomorfológico de detalhe de um hectare, na escala de 1:2.500. Foram escolhidas áreas representativas relacionadas a cada tipo de seção fluvial: confinada, semiconfinada e não confinada (figura 4). Como já dito anteriormente, no trecho não confinado não foi realizado um mapeamento de estilos fluviais, por esse trecho ser considerado apenas uma variação local e de pouca representatividade espacial do trecho semiconfinado.

\section{Mapeamentos dos estilos fluviais na escala de 1:10.000}

Os mapeamentos de estilo fluvial seguiram a tipologia proposta por CORREA et al (2009), sendo editados e aperfeiçoados para os fins deste trabalho. No mesmo trabalho foram publicados em conjunto com o mapeamento as matrizes dos padrões de drenagem das áreas mapeadas, nas quais também foram acrescentadas algumas modificações. A partir dos conjuntos de dados serão feitas algumas considerações.

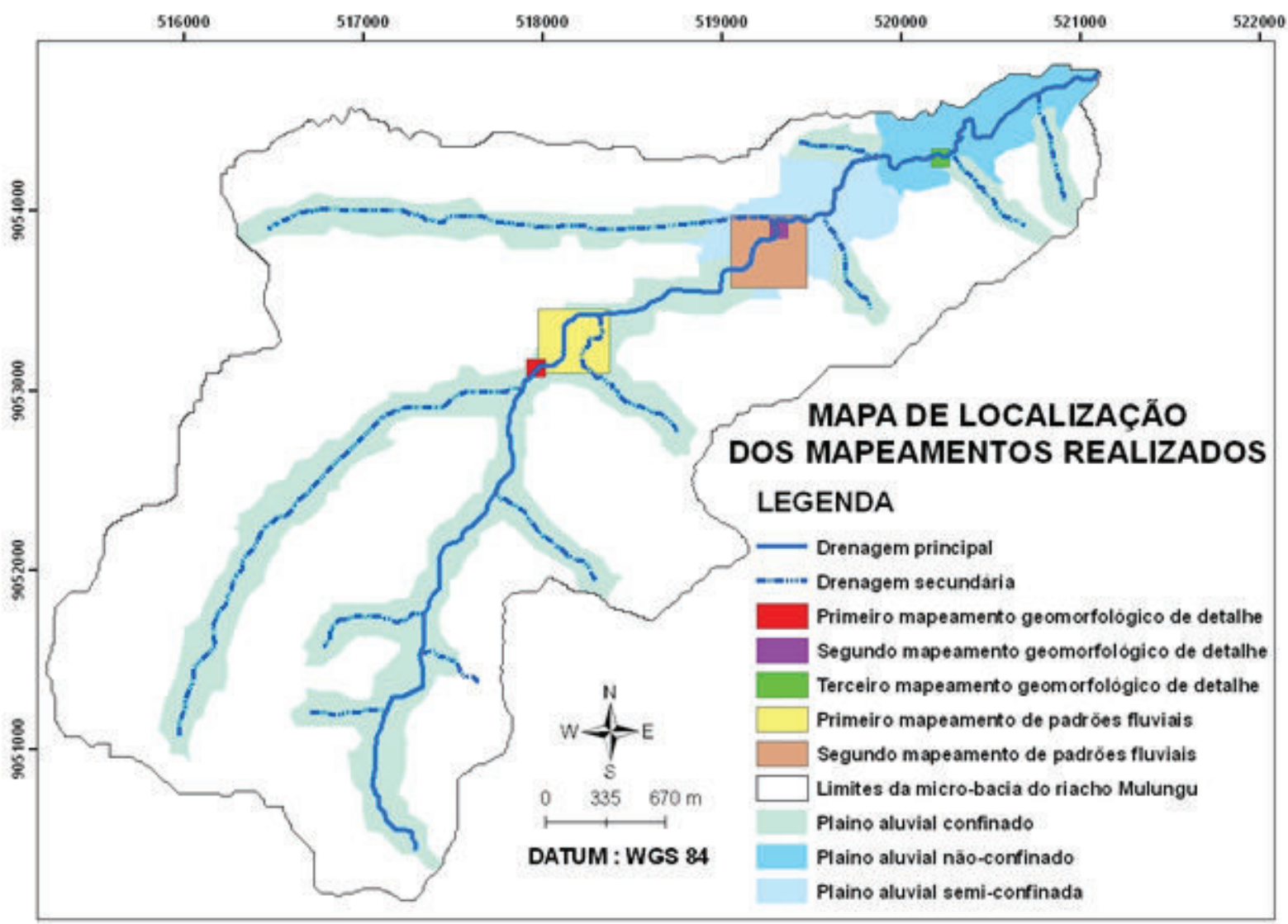

Figura 4 - Mapa de localização das áreas mapeadas

A primeira área mapeada (figura 5 e quadro 1) encontra-se logo após o encontro do riacho Mulungu com seu afluente principal, o riacho Montes, e destaca-se tanto pela predominância de um leito rochoso e soleiras, como pela ação da erosão linear em suas margens com planossolos. Outro ponto interessante a se observar é a presença de uma soleira fluvial em crosta laterítica, cimentando uma cascalheira, que possivelmente funcionava anteriormente como um nível de base local (depósito de canal).

Observam-se, também, as mudanças de direção do curso do canal fluvial, decorrentes, provavelmente, da presença das soleiras, que alteram significantemente a velocidade e o fluxo da água dentro do canal; e consequentemente as relações entre erosão, transporte e sedimentação dentro do 
Quadro 1 - Matriz de informação de um estilo fluvial semiárido - confinado, leito rochoso, com presença de corredeiras e poços

\begin{tabular}{|c|c|}
\hline \multicolumn{2}{|c|}{$\begin{array}{l}\text { CARACTERISTICAS DO SETOR CONFINADO, COM LEITO ROCHOSO, } \\
\text { PRESENÇA DE CORREDEIRAS E POÇAS NO RIACHO MULUNGU }\end{array}$} \\
\hline Tipo de vale & - Confinado. \\
\hline Forma do rio & $\begin{array}{ll}\text { - } & \text { Forma retilínea. } \\
\text { - } & \text { Lateralmente estável. } \\
\text { - } & \text { Forma controlada pelo material geológico. } \\
\text { Baixa sinuosidade. }\end{array}$ \\
\hline Textura do material do leito & $\begin{array}{ll} & \text { Cascalheira fluvial angulosa com eventuais afloramentos rochosos } \\
\text { - } & \text { Barra composta com granudescendência da montante para jusante. } \\
\text { - } & \text { Provável deposição de matriz arenosa em mantos. } \\
\text { - } & \text { Sieve Depinam calhaus e seixos e eventuais blocos angulosos. }\end{array}$ \\
\hline Geometria no Canal da Drenagem & - $\quad$ Ocupando todo o plaino com distribuição assimétrica da barra de cascalho. \\
\hline Unidades Geomórficas & 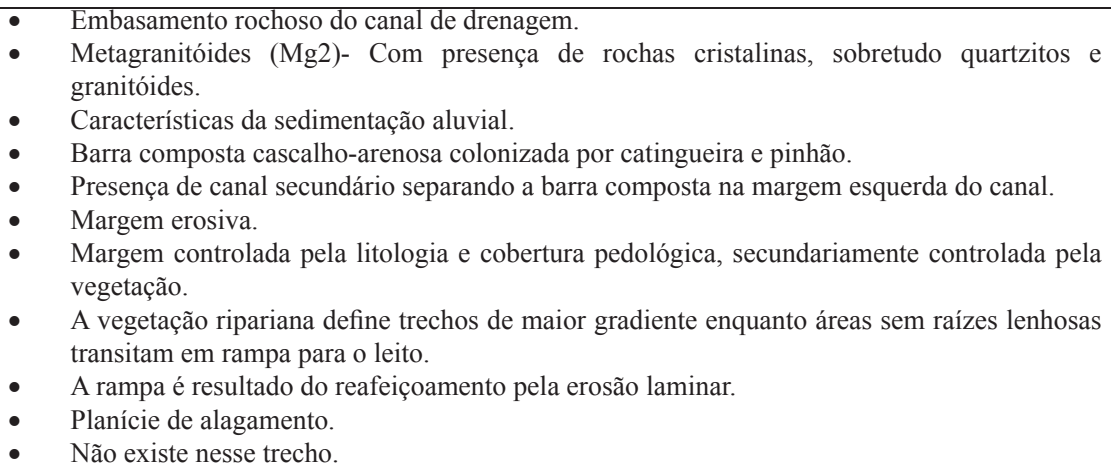 \\
\hline Vegetação Associada & $\begin{array}{ll}\text { - } & \text { No canal de drenagem. } \\
\text { - } & \text { Vegetação arbustiva colonizando barras. } \\
\text { - } & \text { Na planície aluvial. } \\
\text { - } & \text { Não há planície aluvial. }\end{array}$ \\
\hline \multicolumn{2}{|r|}{ COMPORTAMENTO DO RIO } \\
\hline Baixa vazão & Sem vazão. \\
\hline Alta Vazão & - Canal provavelmente atinge o topo da barra. \\
\hline Estágio imediato de extravasamento & - Não há extravasamento. \\
\hline Alagamento sobre as margens & - Não há extravasamento. \\
\hline \multicolumn{2}{|r|}{ CONTROLES } \\
\hline Bacia à Montante & Trecho de cabeceira com cerca de $80 \%$ da bacia. \\
\hline Unidade de Paisagem & - $\quad$ Pedimento dissecado. \\
\hline Zona Processual & Zona de fornecimento e transporte com carga de fundo. \\
\hline $\begin{array}{l}\text { Morfologia do vale (Tamanho e } \\
\text { forma) }\end{array}$ & $\begin{array}{l}\text { - Plaino aluvial levemente entrincheirado no topo do pedimento com largura máxima de } 10 \\
\text { metros. }\end{array}$ \\
\hline Declive do vale & - De 7 a $5 \%$ por cem metros. \\
\hline \multicolumn{2}{|r|}{ TIPOS DE INTERVENÇÕES ANTRÓPICAS } \\
\hline Formas & $\begin{array}{l}\text { - Trecho com mínima intervenção. Observou-se apenas uma cerca cortando o riacho em todo } \\
\text { esse setor. } \\
\text { Também é cortado pela estrada dos postes. }\end{array}$ \\
\hline Processos & - Desmatamento das margens em áreas pontais. \\
\hline OUTROS & $\begin{array}{l}\text { Esse trecho foi caracterizado a partir da observação de um setor específico (onde aparece uma } \\
\text { barra colonizada). Devem ser inseridas outras informações de todo o trecho à montante, pois } \\
\text { embora se possa enquadrá-lo no mesmo setor, apresenta algumas características distintas. }\end{array}$ \\
\hline
\end{tabular}


sistema fluvial. Essa mudança reflete-se nas formas geradas, como a mudança de direção do canal e a formação de poças, que foi influenciada pelas escavações antropogênicas de cacimbas; situação que vai ser melhor ilustrada no mapeamento na escala de 1:2.500.

O trecho em geral apresenta pouca interferência antrópica, sendo esta basicamente presente na construção de uma cerca que atravessa o canal, e representa o início da área de maior presença da ocupação humana no riacho.

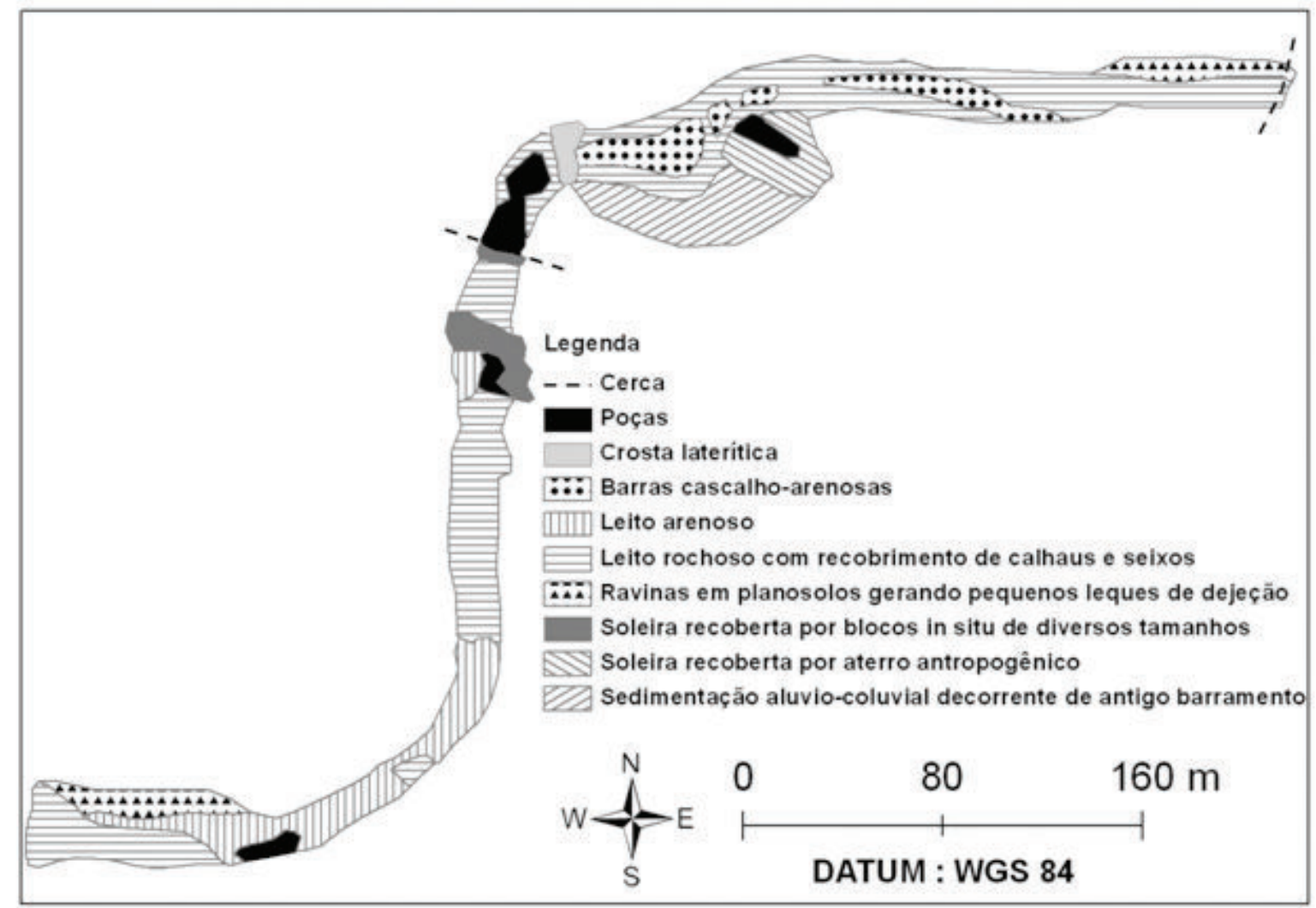

Figura 5 - Planta do canal com estilo fluvial semiárido - confinado, leito rochoso, com presença de corredeiras e poças.

Fonte: SOUZA, 2008; CORRÊA, SILVA, et al., 2009 (adaptado dos autores)

A segunda área mapeada, na escala de 1:10.000, localiza-se antes da barragem do canal principal, e do encontro do riacho Mulungu com outro importante afluente, novamente da margem esquerda (figura 6 e quadro 2). A presença das planícies aluviais em forma de bolsão, que se alternam entre as margens do canal, é a característica mais marcante do trecho. Outra característica física presente é a diminuição das frações granulométricas de recobrimento do leito seco, em relação ao trecho anterior, predominando as frações areia grossa e muito grossa.

Nesse trecho já se observa uma maior ocupação humana, com atividades agrícolas sobre as planícies em bolsão. Também foi observada um maior parcelamento da terra, representado pelas várias cercas que cruzam o rio nesta área, denotando assim sua importância econômica e o fato de ser o setor mais populoso da bacia. Além disso, há a presença de algumas cacimbas escavadas no leito arenoso do riacho.

A presença de uma barragem, que estava rompida na época das campanhas de campo, também alterou significantemente as formas e os processos deste trecho do riacho. Observa-se uma drenagem lateral, que tinha sido barrada, e durante esse "barramento" a sedimentação da drenagem principal por sobre a planície em bolsão obstruiu a continuidade da drenagem lateral. Essa última, na época das visitas, ainda não tinha competência para vencer a obstrução criada pela sedimentação da drenagem principal. 
Quadro 2 - Matriz de informação de um estilo fluvial semiárido - vale meandrante e controlado por planície de inundação descontínua

\begin{tabular}{|c|c|}
\hline \multicolumn{2}{|c|}{ CARACTERÍSTICAS DO SETOR SEMI-CONFINADO DO RIACHO MULUNGU } \\
\hline Tipo de vale & • $\quad$ Semiconfinado. \\
\hline Forma do rio & $\begin{array}{ll} & \text { Forma meândrica. } \\
\text { - } & \text { Lateralmente instável. } \\
\text { - } & \text { Forma controlada pela sinuosidade (média) do fluxo. } \\
\text { - } & \text { Média sinuosidade. } \\
\text { - } & \text { Deposição de barras laterais arenosas (com cascalho também). } \\
\text { Forma controlada pelo próprio aluvião. }\end{array}$ \\
\hline Textura do material do leito & $\begin{array}{l}\text { - Areia grossa com pequenas barras longitudinais cascalho arenosas. } \\
\text { O cascalho têm predominância de grânulos e seixos angulosos e subangulosos (ausência de } \\
\text { calhaus e blocos). }\end{array}$ \\
\hline Geometria no Canal da Drenagem & $\begin{array}{l}\text { - } \quad \text { Cortando a sedimentação aluvial em meandros de morfologia assimétrica. } \\
\text { - } \quad \text { Alternando barras nas margens convexas e margens erosivas do lado côncavo. } \\
\text { - Margens côncavas conservadas pelo enraizamento da vegetação ripariana. }\end{array}$ \\
\hline Unidades Geomórficas & 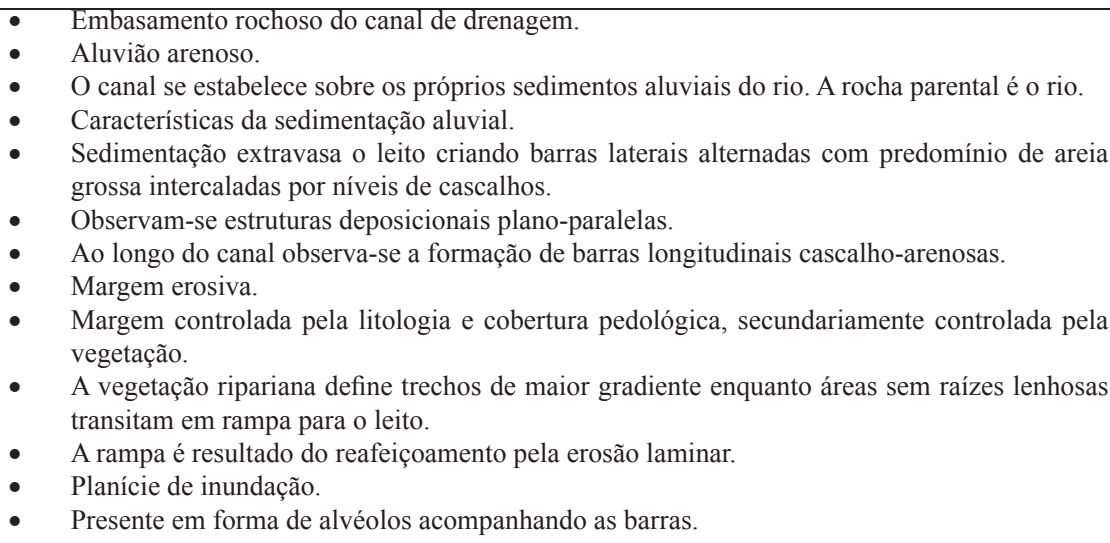 \\
\hline Vegetação Associada & $\begin{array}{l}\text { - } \quad \text { No canal de drenagem. } \\
\text { - } \quad \text { Vegetação ripariana exótica (algaroba). } \\
\text { - } \quad \text { Na planície aluvial. } \\
\text { Desmatado para cultivo, permanecendo apenas algumas árvores isoladas. }\end{array}$ \\
\hline \multicolumn{2}{|r|}{ COMPORTAMENTO DO RIO } \\
\hline Baixa vazão & Sem vazão. \\
\hline Alta Vazão & Canal provavelmente atinge o topo das barras laterais. \\
\hline Estágio imediato de extravasamento & $\begin{array}{l}\text { - } \quad \text { Estágio alto marcado por deposição além do canal com acumulação de níveis de cascalho } \\
\text { sobre as barras. } \\
\text { - } \quad \text { Carga mista (fundo e suspensão). }\end{array}$ \\
\hline Alagamento sobre as margens & Extravasamento por sobre toda a planície de inundação funcional. \\
\hline \multicolumn{2}{|r|}{ CONTROLES } \\
\hline Bacia à Montante & Médio e alto curso com cerca de $90 \%$ da bacia. \\
\hline Unidade de Paisagem & Planícies aluviais embutidas nos pedimentos. \\
\hline Zona Processual & Área deposicional e de transferência de sedimentos ao longo do canal. \\
\hline $\begin{array}{l}\text { Morfologia do vale (Tamanho e } \\
\text { forma) }\end{array}$ & $\begin{array}{l}\text { - } \quad \text { Marcado pelo recuo do knick-point dos pedimentos. } \\
\text { - } \quad \text { Planície aluvial em bolsão com até } 30 \text { metros de largura. }\end{array}$ \\
\hline Declive do vale & $\bullet \quad<5 \%$ por 100 metros. \\
\hline \multicolumn{2}{|r|}{ TIPOS DE INTERVENÇÕES ANTRÓPICAS } \\
\hline Formas & $\begin{array}{l}\text { - Máxima intervenção. Comumente cortado por cercas. Cacimbas. Barragens nos afluentes. } \\
\text { Cultivos. Moradias nos pedimentos. }\end{array}$ \\
\hline Processos & $\begin{array}{l}\text { - Barramento de drenagens laterais e principal (barragens de concreto ou madeira). Escavação. } \\
\text { Aração da terra nas barras. }\end{array}$ \\
\hline OUTROS & $\begin{array}{l}\text { Subida do nível de base do leito principal e das drenagens laterais bloqueadas. Colmatação } \\
\text { por sedimentos arenosos grossos com estrutura laminada. É importante diferenciar a parte } \\
\text { terminal desse setor (parte da barragem), onde predomina a sedimentação de argila por } \\
\text { suspensão e onde não há transição brusca entre planície e pedimento. }\end{array}$ \\
\hline
\end{tabular}


A presença dos meandros neste setor pode ser entendida como uma influência da barragem da drenagem principal, que teria diminuído a velocidade do fluxo de água, o que aumentaria a sedimentação na área, resultando assim na possibilidade da criação dos meandros. Sobre a mudança de ângulo mais brusca que ocorre por volta do meio desse trecho, esta se deve ao afloramento de uma soleira rochosa na margem esquerda. A parte central desse trecho será melhor analisada no mapeamento na escala de 1:2.500, logo em seguida.

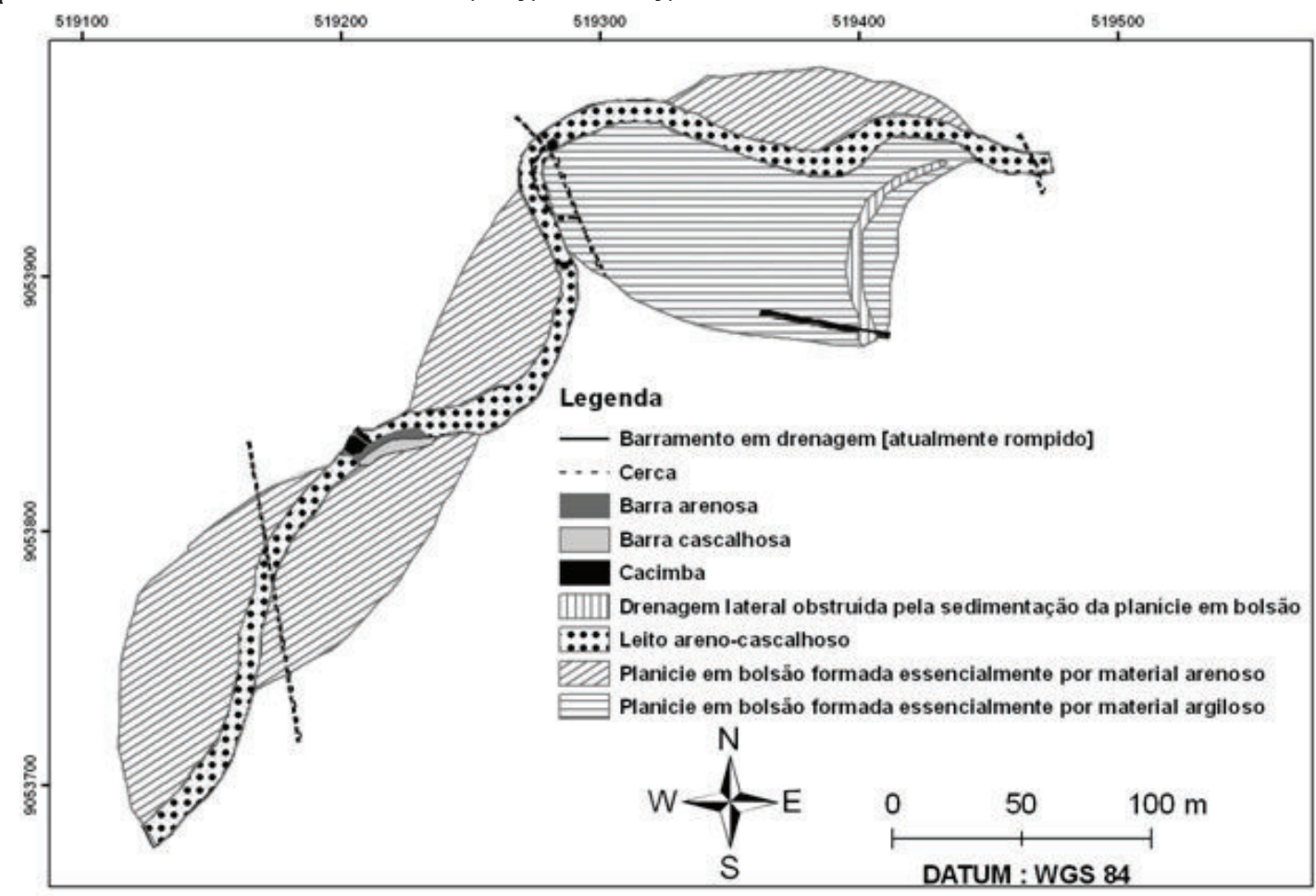

Figura 6 - Mapa do estilo fluvial do riacho Mulungu, trecho semiconfinado com vale meandrante e controlado por planície de inundação descontínua

Mapeamento geomorfológico de detalhe na escala de 1:2.500

Foram realizados três mapeamentos geomorfológicos em áreas de um hectare na escala de 1:2.500. Essas áreas foram distribuídas entre os três tipos de trechos classificados: confinado, semi-confinado e não-confinado; tentando-se sempre escolher áreas com características representativas desses trechos. Nessa escala de trabalho é possível detalhar as pequenas formas presentes no sistema fluvial, como também abordar as estruturas superficiais presentes.

Foi escolhida uma área do trecho não-confinado para se fazer o mapeamento, mesmo sem esse trecho ter sido contemplado pelo mapeamento de estilo fluvial na escala de 1:10.000, para que se pudesse demonstrar os impactos causados pela construção e posterior rompimento da barragem da drenagem principal no trecho.

O primeiro mapeamento de detalhe foi realizado no trecho exatamente anterior ao mapeamento de estilo fluvial do trecho confinado, ou seja, no encontro do riacho Mulungu com o riacho Montes, seu principal afluente (figura 7). Deste modo esse mapeamento encontra-se dentro do trecho confinado e de pouco uso do riacho. A vegetação nesse trecho ainda se encontra conservada, inclusive a vegetação ripária se faz presente em praticamente todo trecho.

A principal característica que se observa é a concentração de material arenoso adjacente ao encontro entre os dois riachos, que proporcionou a possibilidade de escavações de cacimbas para obtenção de água pelos moradores. Entretanto, é visível a relação entre as cacimbas escavadas no leito arenoso e as depressões com crescimento de crosta salina, o que denota uma relação direta entre as escavações e o aumento da concentração de sais em superfície. 
Outro ponto de interesse é a margem em planossolo com erosão linear, o que pode se justificar pela propensão a erosão dos planossolos em virtude do seu forte gradiente textural e pelas variações da direção e velocidade do fluxo na margem erosiva, variações essas, possivelmente, provenientes da alteração da forma do leito causada pela escavação deliberada de cacimbas.

A região que apresenta ravinamento no fim do interflúvio entre a drenagem principal e a drenagem secundária, também deve ser levada em consideração. Isso ocorre justamente após uma ruptura plana no pedimento, o que causa um aumento na capacidade erosiva do escoamento superficial e conseqüentemente a passagem do escoamento superficial difuso para a erosão linear. Nas outras áreas onde há esse mesmo tipo de ruptura o recobrimento por pavimento detrítico é mais denso, deste modo protegendo o solo contra erosão linear.

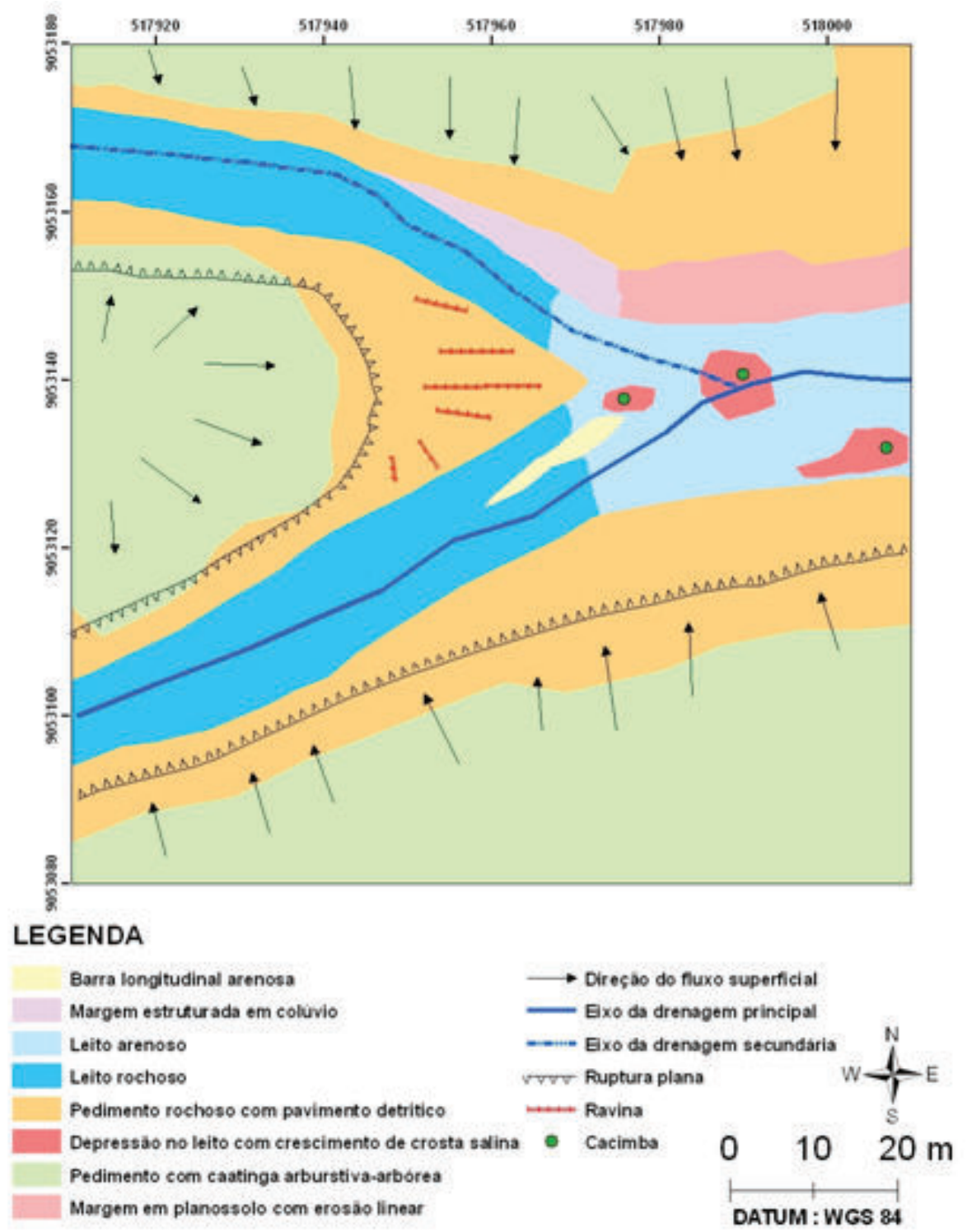

Figura 7 - Primeiro mapeamento geomorfológico de detalhe em área de um hectare, em trecho confinado do riacho Mulungu

O segundo trecho está contido dentro do mapeamento de estilo fluvial do trecho semi-confinado. Decidiu-se mapear essa área, na escala de 1:2.500, por ela ser representativa do trecho semi-confinado e por ela conter uma mudança brusca de direção do canal principal, e deste modo tentar analisar os detalhes representativos do trecho e também dessa mudança de direção (figura 8). 


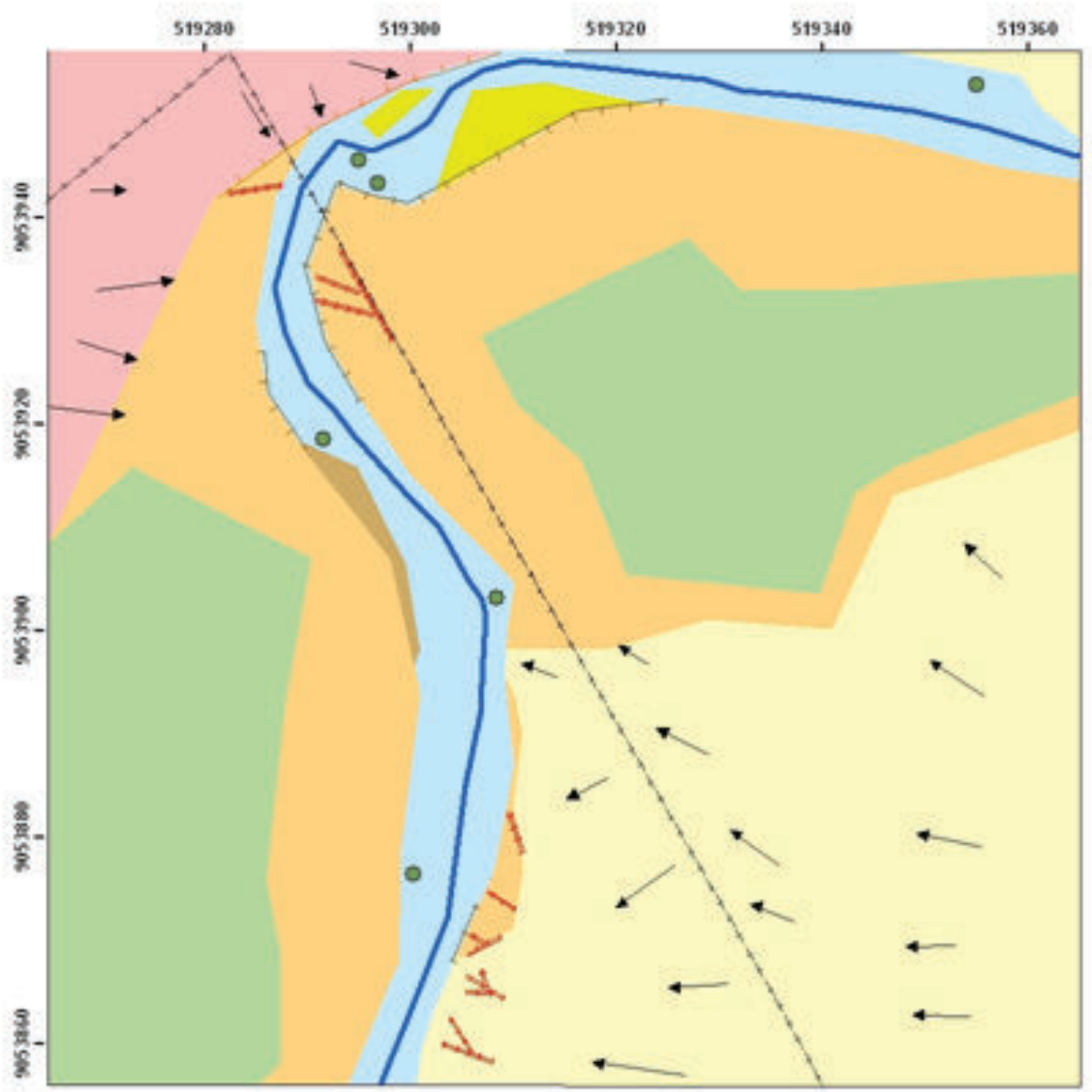

\section{LEGENDA}

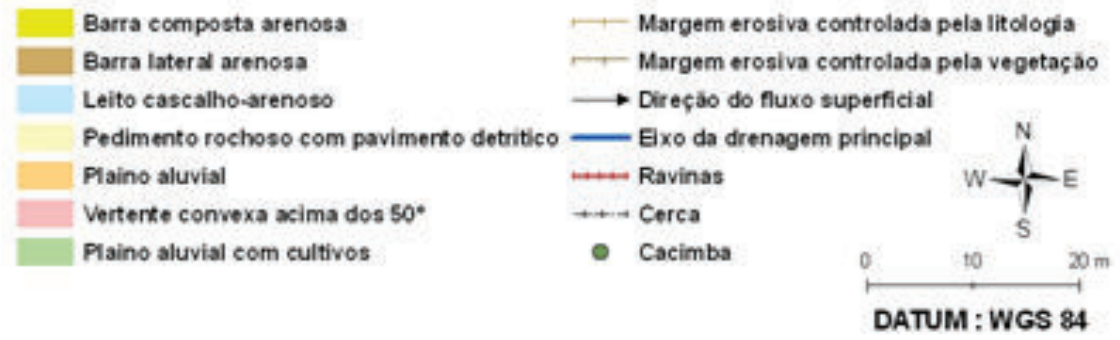

Figura 8 - Segundo mapeamento geomorfológico de detalhe em área de um hectare, em trecho semi-confinado do riacho Mulungu

A mudança de direção do canal fluvial advém, basicamente, do afloramento da rocha mãe que acaba formando uma vertente íngreme e força o riacho a mudar de direção.

Contudo, o ponto de maior interesse nessa área são os impactos das ações antrópicas no sistema fluvial. Esses basicamente provêm de duas fontes: construção de cercas que atravessam o canal; e principalmente a escavação de cacimbas no leito do canal. Em ambos os casos o padrão de velocidade e turbulência do fluxo é alterado e com isso modificações no sistema fluvial são criadas.

O resultado dessas mudanças apresenta-se diretamente pelas formas e localização das margens erosivas, o que por sua vez altera a forma do canal. Os dois pontos principais dessas mudanças são: a área posterior à barra lateral arenosa na margem esquerda; e a área logo após a cerca que cruza o riacho; podendo até as duas áreas serem consideradas uma única área de perturbação do fluxo no canal.

Na primeira parte observou-se uma cacimba posterior à barra arenosa, que modificando a forma do leito, aumenta a turbulência do fluxo de água e seu direcionamento, e com isso acaba formando margens erosivas onde normalmente elas não estariam presentes.

$\mathrm{Na}$ segunda parte a presença da cerca e das cacimbas modificou severamente a forma do canal. A margem erosiva esquerda está sendo controlada pela litologia (a localização dessa margem 
concorda com o padrão de localização de margem erosiva em canais meandrantes). Por outro lado, a margem direita que deveria estar conservada, onde inclusive poderia haver a presença de uma barra lateral (do tipo ponta de meandro), apresenta-se instável e distinta do padrão comum. A margem direita apresenta uma forte erosão e há a presença de uma barra composta, aparentemente instável, também bastante atacada pela erosão. Neste ponto é visível a alteração morfológica da margem direita do canal.

A erosão linear na área decorre de três situações: do contato pedimento com o plaino aluvial, o que resulta em descontinuidades favorecendo a erosão linear (presente do lado da margem direita ao sul do mapa); da turbulência causada pela cerca no fluxo de água superficial, o que aumenta o poder erosivo do fluxo (presente do lado da margem direita ao norte do mapa); e devido à aceleração do fluxo resultante da passagem do fluxo pela vertente íngreme formada diretamente pelo pedimento rochoso, que também aproveita a descontinuidade do contato com o plaino aluvial (presente do lado da margem esquerda nas proximidades da vertente convexa).

O terceiro mapeamento de detalhe representa a área logo após a barragem da drenagem principal, e tem sua importância, no estudo em tela, pelo impacto antrópico observado nela. Nesse nível de detalhe é possível verificar várias alterações tecnogênicas na área (figura 9).

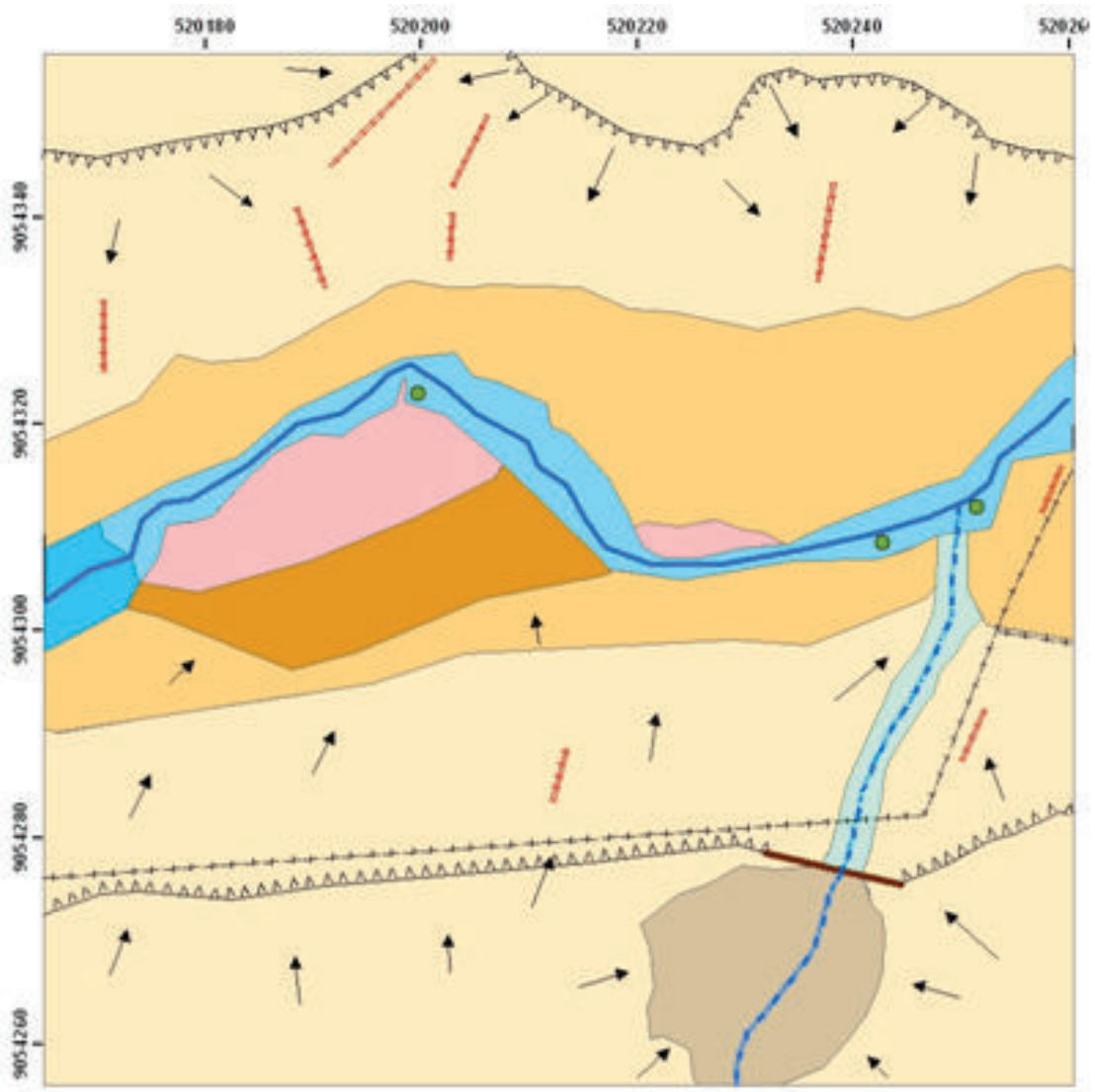

\section{LEGENDA}

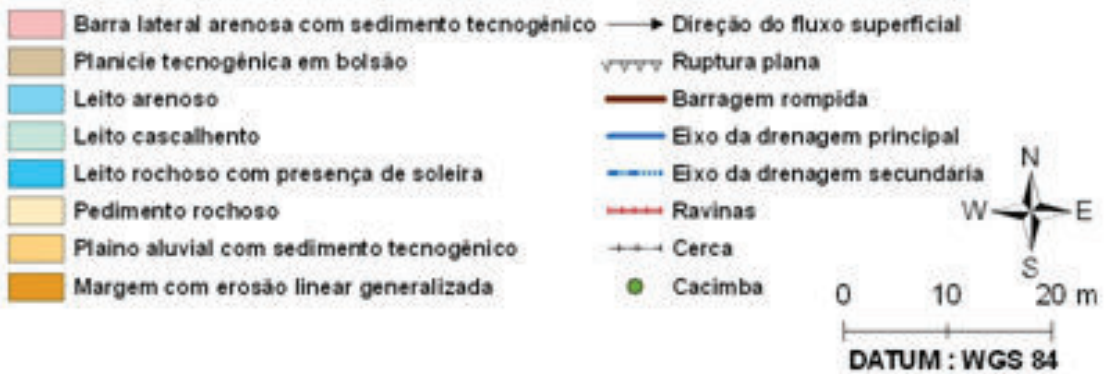

Figura 9 - Terceiro mapeamento geomorfológico de detalhe em área de um hectare, em trecho não-confinado do riacho Mulungu 
O primeiro ponto é a retirada da vegetação arbustiva, ocasionando a predominância de vegetação herbácea na época chuvosa Durante o período de estiagem o solo fica descoberto, e no início das chuvas torrenciais há uma grande produção de sedimentos e erosão linear.

As cercas aumentam a turbulência do fluxo, o que também ocasiona um agravamento na erosão. As rupturas de declive também alteram o fluxo superficial aumentando a possibilidade de erosão, que no caso é potencializado pelo tipo de uso da terra.

$\mathrm{Na}$ área também há um barramento da drenagem secundária nos moldes de construção na região, e que como muitas outras barragens do riacho encontra-se rompido. Como em outros setores, aqui também se observa a construção de uma planície tecnogênica em bolsão resultante do barramento e da rápida colmatação do espaço de acomodação gerado pela barragem. Contudo, o maior impacto na área foi ocasionado pela construção e posterior rompimento da barragem da drenagem principal, que se localiza a montante da área.

Inicialmente, com a construção da barragem, o aporte de sedimentos diminuiu, o que faz com que o fluxo de água tivesse uma capacidade maior de erosão, e deste modo aumentasse a incisão no canal principal. Com o rompimento da barragem, uma grande quantidade de sedimentos e detritos tecnogênicos recobriu as áreas a jusante. Esse recobrimento de sedimentos e detritos tecnogênicos soterrou boa parte do plaino aluvial a jusante, inclusive a área onde o aumento da incisão da drenagem já tinha revelado o próprio pedimento rochoso, gerando assim um novo recobrimento por sedimentos aluviais e detritos tecnogênicos, o que prejudicou diretamente a atividade agrícola na área.

\section{CONSIDERAÇÕES FINAIS}

Diante da falta de estudos de detalhe sobre a drenagem de baixa ordem no semiárido do Nordeste brasileiro, o presente trabalho visou lançar uma nova perspectiva escalar e processual sobre os estudos de geomorfologia fluvial no ambiente semiárido brasileiro.

A área em questão mostrou-se fortemente afetada pela intervenção antrópica, apesar de sua posição remota dentro do core semiárido do Nordeste. A principal intervenção sobre a morfologia do canal fluvial advém da construção de inúmeras barragens domésticas. A rápida colmatação das mesmas, no entanto, acaba favorecendo o seu rompimento e desencadeando processos agressivos de erosão linear. A cabeceira de drenagem do canal principal foi cortada por uma estrada, sendo esse problema recorrente em toda região, o que modifica severamente a direção da drenagem local e aumenta o aporte de clastos, além de causar graves transtornos para o transporte dos residentes nas épocas de chuva.

Essas modificações alteram significantemente os processos dentro do sistema fluvial, o que reflete direta e indiretamente na manutenção e evolução das planícies de inundação do médio e baixo curso, e por fim afeta as atividades agrícolas exercidas nelas.

Dentro desse mesmo contexto pode-se verificar a importância de pequenas intervenções antrópicas, como as cacimbas e as cercas, ao longo do leito e sua influência desestabilizadora dentro do sistema fluvial.

A diferenciação nas escalas e níveis de detalhe empregados nos mapeamentos oferece a possibilidade de se compreender o sistema fluvial a partir de diferentes contextos e possibilidades de uso da terra.

A escala de 1:25.000 possibilita uma visão macro das características físicas e antrópicas da área, sendo avaliadas as grandes características geomorfológicas e as mais importantes atuações antrópicas. Os mapeamentos dos estilos fluviais nesta escala possibilitaram um maior detalhamento de dois perfis longitudinais do canal principal, além de favorecer a compreensão das relações de processos, formas e controles dentro do canal fluvial, o que é de extrema importância para o entendimento do sistema fluvial. 
Os mapeamentos geomorfológicos de detalhe na escala de 1:2.500, permitiram uma análise integrando características locais e detalhadas, como a relação entre a morfologia e a estrutura superficial da paisagem, ou da morfologia com o uso da terra.

Ao mesmo tempo que se pensa o sistema fluvial nessas três escalas de detalhe distintas, há a possibilidade de se integrar as informações obtidas em cada uma delas, deste modo podendo-se detalhar mais o estudo sem perder o referencial único do sistema fluvial como um todo. A partir da compreensão do sistema fluvial, pode-se inferir condições e comportamentos básicos naturais do sistema fluvial local e relacionando esse sistema físico com o sistema antrópico de atuação, pode-se avaliar as modificações e impactos antropogênicos no sistema.

Posteriormente, a partir da análise das características e dos impactos no sistema fluvial, pode-se pensar em métodos e formas para se mitigar os problemas resultantes desses impactos e assim pensar em planejamento local, de forma sistêmica e embasada. Deste modo, é notória a necessidade de estudos sobre as características e o comportamento do sistema fluvial para que se possa fazer um planejamento local eficaz e para que se evite o avanço da degradação em ambiente fluvial semi-árido.

Outro ponto necessário de se avaliar são os estudos relacionados com a aplicação de referenciais teóricos como o de sensitividade da paisagem (BRUNSDEN, 2001; CORRÊA, 2006), que preconizam a ocorrência intermitente e espasmódica de eventos desestabilizadores das unidades de paisagem, cuja recursividade pode ser recuperada apenas mediante o uso de uma abordagem escalar adequada. Esses estudos ajudariam a evitar problemas encontrados na bacia, tais como os rompimentos das barragens e a retomada agressiva da erosão linear.

\section{REFERÊNCIA BIBLIOGRÁFICA}

ARGENTO, M. S. Mapeamento geomorfológico. In: GUERRA, A. J. T.; CUNHA, S. B. Geomorfologia: uma atualização de bases e conceitos. 3. ed. Rio de Janeiro: Bertrand Brasil, 1998. p. 365-391.

BIGARElla, J. J.; SUGUIO, K.; BECKER, R. D. Ambiente Fluvial: Ambientes de Sedimentação, sua interpretação e importância. 1a. ed. Curitiba: Editora da Universidade Federal do Paraná. Associação de Defesa e Educação Ambiental, 1979.

BOTELHO, R. G. M. Planejamento ambiental em microbacia hidrográfica. In: GUERRA, A. J. T.; SILVA, A. S.; BOTELHO, R. G. M. Erosão e Conservação dos Solos - conceitos, temas e aplicações. 2. ed. Rio de Janeiro: Bertrand Brasil, 2005. p. 269-300.

BRIERLEY, G. J.; FRYIRS, K. A. Geomorphology and River Management: Applications of the River Styles Framework. Oxford: Blackwell Publications, 2005.

BRUNSDEN, D.; THORNES, J. B. Landscape Sensitivity and Change. Transactions of the Institute of British Geographers, New Series, v. 4, n. 4, p. 463-484, 1979.

CARVALHO, T. M.; BAYER, M. Utilização dos produtos da "Shuttler Radar Topography Mission" (SRTM) no mapeamento geomorfológico do estado de Goiás. Revista Brasileira de Geomorfologia, v. 9 n.1, p. 35-41, 2008.

CARVALHO, T. M.; LATRUBESSE, E. M. Aplicação de modelos digitais do terreno (MDT) em análises macrogeomorfológicas: o caso da bacia hidrográfica do Araguaia. Revista Brasileira de Geomorfologia, v. 5 n.1, p. 85-93, 2004.

CHRISTOFOLETTI, A. Geomorfologia. São Paulo: Edgar Blücher, 1980.

CHRISTOFOLETTI, A. Geomorfologia Fluvial. São Paulo: Editora Edgard Blucher, 1981.

CHRISTOFOLETTI, A. Modelagem de sistemas ambientais. São Paulo: Edgar Blüncher, 1999.

CORRÊA, A. C. B.; SOUZA, J. O. P.; CAVALCANTI, L. C. S. Solos do ambiente semi-árido brasileiro: erosão e degradação a partir de uma perspectiva geomorfológica. [S.1.]: [s.n.], em prelo.

CPRM - SERVIÇO GEOLÓGICO DO BRASIL. Projeto cadastro de fontes de abastecimento por água subterrânea. Diagnóstico do município de Belém de São Francisco, estado de Pernambuco. CPRM/ PRODEEM. Recife. 2005. 
DREW, D. Processos interativos homem-meio ambiente. 6. ed. Rio de Janeiro: Bertrand Brasil, 2005.

EMBRAPA. Zoneamento Agroecológico do Estado de Pernambuco - ZAPE. Recife: Embrapa Solos/ Governo do Estado de Pernambuco - Secretaria de Produção Rural e Reforma Agrária, 2001. CD-ROM. (Embrapa Solos. Documentos, 35), 2001.

FRYIRS, K.; BRIERLEY, G. Practical application of the River Styles ${ }^{\circledR}$ framework as a tool for catchment-wide river management: A case study from Bega catchment, New South Wales, Australia. ebook: site: http://www.riverstyles.com/ebook.php, 2005.

GRAF, W. L. Fluvial Process in Dryland Rivers. Caldwell: The Blackburn Press, 1988.

GUIMARÃES, D. P.; LANDAU, E. C.; COSTA, T. C. C. Relevo digital dos municípios brasileiros. Sete Lagoas: EMBRAPA Milho e Sorgo, 2008.

LEOPOLD, L. B.; WOLMAN, M. G.; MILLER, J. M. Fluvial process in geomorphology. Mineola: Dover Publications, INC, 1964.

MARTINELLI, M. E.; PEDROTTI, F. A cartografia das unidades de paisagem: questões metodológicas. Revista do Departamento de Geografia - São Paulo, v. 14, p. 39-46, 2001.

MATTOS, S. H. V. L.; PEREZ FILHO, A. Complexidade e estabilidade em sistemas geomorfológicos: uma introdução ao tema. Revista Brasileira de Geomorfologia, v. 5 n.1, p. 11-18, 2004.

OLIVEIRA, P. C. A.; RODRIGUES, S. C. Cartografia do relevo: um estudo aplicado na região oeste de Minas Gerais. Revista Brasileira de Geomorfologia, v. 8 n.2, p. 37-44, 2007.

OLIVEIRA, S. N. et al. Delimitação automática de bacias de drenagem e análise multivariada de atributos morfométrico usando modelo digital de elevação hidrologicamente corrigido. Revista Brasileira de Geomorfologia, v. 8 n.1, p. 3-21, 2007.

PINHEIRO, E. S.; KUX, H. J. H.; VILLWOCK, J. A. O potencial de imagens QUICKBIRD para análise de um setor do Planalto das Araucárias, RS: Centro de Pesquisas e Conservação da natureza Pró-Mata. Revista Brasileira de Geomorfologia, v. 6 n.2, p. 65-73, 2005.

RODRIGUES, S. C. E.; BRITO, J. L. S. Mapeamento geomorfológico de detalhe - uma proposta de associação entre o mapeamento tradicional e as novas técnicas em geoprocessamento. Caminhos de Geografia 1(1): 1-6. 2000., v. 1(1), p. 1-6, 2000.

SCHUMM, S. A. The fluvial system. Caldwell: The Blackburn Press, 1977.

SUGUIO, K. Dicionário de geologia sedimentar e áreas afins. Rio de Janeiro: Bertrand Brasil, 1998.

THOMS, M. Floodplain-river ecosystems: lateral connections and implications of human interference. Geomorphology, v. 56, p. 335-349, 2003.

THORNES, J. B.; BRUNSDEN, D. Geomorphology \& Time. London: Methuen \& Co, 1977.

VALERIANO, M. M. Modelo digital de variáveis morfométricas com dados SRTM para o território nacional: o projeto TOPODATA. Anais do XII Simpósio Brasileiro de Sensoriamento Remoto. Goiânia: [s.n.]. 2005.

VALERIANO, M. M.; ROSSETTI. Topographic modelling of Marajó island with SRTM data. Revista Brasileira de Geomorfologia, v. 9 n.1, p. 53-64, 2008.

WALLING, D. E.; WEBB, B. W. Erosion and sediment yield: a global overview. In: Erosion and Sediment Yield: Global and Regional Perspectives, v. 236, p. 3-19, 1996.

Trabalho enviado em outubro de 2011

Trabalho aceito em dezembro de 2011 